\title{
触覚情報を利用したバイオメトリクス認証法*
}

\author{
中野健*1, 兵頭 潤*2, 立石朋 也*2
}

\section{Biometric Authentication Method using Tactile Information}

\author{
Ken NAKANO*3, Jun HYODO and Tomoya TATEISHI \\ *: (iraduate School of Environment and Information Sciences, Yokohama National University, \\ 79) T Tokiwadai. Hodogaya ku. Yokohama shi, Kanagawa, 240 8501 Japan
}

\begin{abstract}
In recent years, security problems have been concerned in the well-developed information society. Although authentication methods such as password-systems and key-systems are used widely, various problems are pointed out. Therefore, biometric authentication which uses the information of personal characteristics is highly paid attention to. In the present study, a new biometric authentication system using finger friction is proposed. This system utilizes tactile information of which recording and playing technologies have not been established, in contrast to visual and auditory information. Moreover, it is using both physical characteristics related to the 3I) shapes of fingerprints and behavioral characteristics related to the way of rubbing. In the present system, I'ZT sensors generate frictional signals when a subject rubs them with its finger. As the result of verification, it is found that some statistics and dynamic programming enable to identify the subject with the frictional signals.
\end{abstract}

Key Words : Friction, Sensor, Dynamic Programming, Biometric Authentication, Tactile Sensation

\section{1. はじめに}

近年の情報通信技術の発展は，インターネットをは じめとする新たな情報インフラ基盤を構筑し，社会・ 経済活動の形態そのものが大きく恋化しつつある。 そ れにともない様々な情報の電子化が急速に進み，情報 セキュリティの観点から, 主としてオンライン上で固 人認証を必要とする場面か㙕加している.

こうした社会的背景のもと, 注目を集めているのが バイオメトリクス認証(1)〜(3) である. バイオメトリク 入認証では，手指の指紋や眼球の虹彩など, 個々に特 有な生体情報によって個人認証を行うため, 従来のパ スワード方式における忘却・漏洩や, 証明書（鍵・カ ード）方式における紛失・盗難などのトラブルを回避 することができる. しかし，システムのコストやサイ ズなどの技術的問題や，偽造という新たな社会的問題 などから，その普及か妨げられている。

本研究で提案する新しいバイオメトリクス認証法 は，手指と力感知型センサ間の摩擦信号を生体情報と

* 原稿受付 2004 年 11 月 5 月1

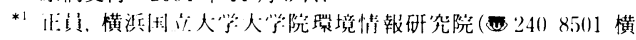

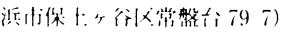

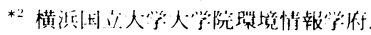

E mail : nakanos ynuac.jp
して利用する. 以後この手法を『摩擦認証』と呼ぶこ とにする. バイオメトリクス認証は，身体的特徴を利 用する手法と行動的特徵を利用する手法に大別でき るが，指紋認証に代表される前者は偽造に弱く，署名 認証に代表される後者は認証率が低いと言われてい る. 摩擦認証では，指紋を含む手指の立体的な凹凸形 状(身体的特徵) と, 手指の押しつけ方やすべらせ方(行 動的特徵）によって摩摖信号が決まるため，両特徴を 融合した手法であると言える.

また視点を変えれば, 既存のバイオメトリクス諗証 が視覚情報または聴覚情報を利用してきたのに対し て, 本手法か浰用するのは触覚情報である。視覚・聴 覚情報は現存のテクノロジーによって記録・再生が可 能なため, 比較的偽造か溶易になるが，触覚情報を記 録・再生する術を持たない現在，本手法は偽造に対す る高い頑強性か澌待できる.さらにそのシステムを安 価に構築できれば，社会的ニーズの高い技術を提供で きるはずである.

以上のコンセプト成立の可否を探るために，単純な 試作システムを用いた実験的検討を行った。 ただし力 感知型センサとしては, 上記経済性の要請から, 安価 な板状王電素子を用いた，その結果，本システムは今 回依頼した被験者 14 名全員を識別することができた ので，その詳細を報告する. 


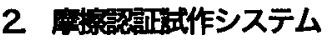

試作機の概観写真と模式図を図 1 に示す，本試作 機は，力感知型センサとしての 2 枚の板状圧電素子 と，そ机らの上端をなめらかに手指でこするためのガ イドから構成されている。

用いたセンサは市販のセラミックスピーカ用素子 (応用電子研究所製) で, 基板材質 : 42アロイ, 基板 サイズ : $25 \mathrm{~mm} \times 12 \mathrm{~mm} \times 0.05 \mathrm{~mm}$ ，压電材質：千夕 ン酸ジルコン酸鉛のユニモルフ型である. 今回は信号 取得の容易さから, 手指で摩擦する方向 (X力向)に 対して面か活直，長手方向力粎向き（Z方向）になる ように，同センサ 2枚を配置した，センサユニット 周辺の構造を図 2 に示す。本ユニットは, 行動的特 徵を排除した場合の実験（3.1 節参照）のために， ス テッピングモータ駆動の X軸直動ステージ上に設置 した.

手指のすべりをサポートするためのガイドはアク リル製で，手指を押しつけたときに手指の腹部がガイ ド下端を越えてセンサ上端に接触するよう, 幅 $6 \mathrm{~mm}$ の空つき V字淟（半頂角：60度）とした，また，ガ イド下端とセンサとの間隔を調節するために, ガイド

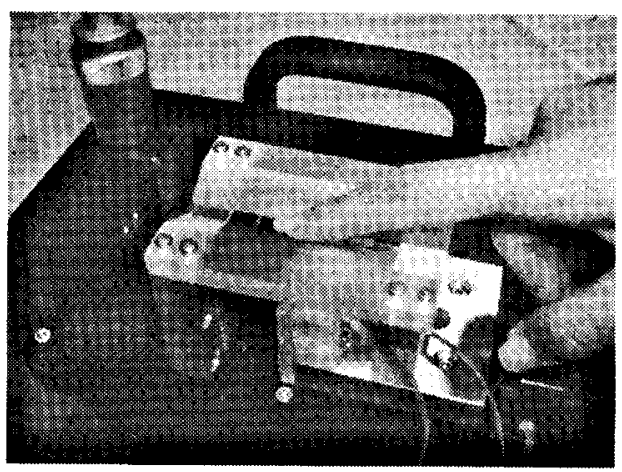

(a) Photograph of experimental apparatus

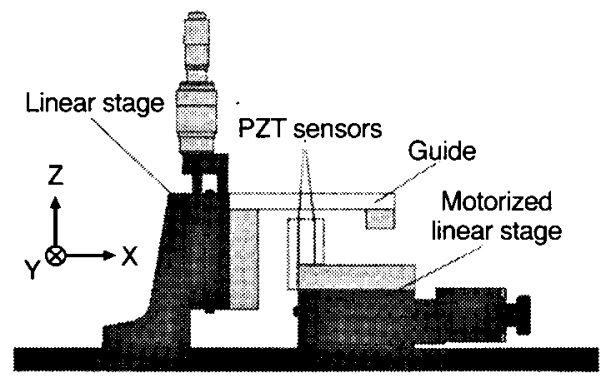

(b) Schematic diagram of experimental apparatus Fig.1 Experimental apparatus
はZ 軸直動ステージ上に設圆した，本夷験ではその 間隔を $0.1 \mathrm{~mm}$ に設定した。

手指との摩擦によってセンサが発する 2 系列の摩 摖信号は，ディジタルデータレコーダを用いて取得し た. 本実験ではサンプリング周波数を $2.5 \mathrm{kHz}$ とした。 以上により得られた摩擦信号は，ディジタルフィルタ によるデータ処理，DPマッチングによる照合計算な ぞ,すべてパーソナルコンピュータ.たで解析を行った。

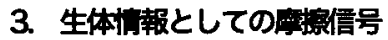

3.1 身体的特徽に関する模㣙 目頭に述べた コンセプト成立のための大前提として，指紋を含む手 指の凹凸形状情報か摩擦信号に内包される必要があ る.すなわ行動的特徵を排除して，身体的特徴のみ を抽出したとき，それか終生不変かつ万人不同である ことが望ましい，そこでまず，被験者の右手示指先端 をガイド上に置いてもらい，X軸值動ステージによっ てセンサュニットを移動して摩摖信号を取得した。 た だし物体表面の自然なこすり方を念頭に置いて，手 指の配置およびセンサユニットの移動はX軸負方向， 速度は $10 \mathrm{~mm} / \mathrm{s}$ とした。

被験者 $\mathrm{A} の 2$ 回分の結果を図 3 に示寸。ここで図 中のCh.1 は図 I(b) に抢いて左側（上流側）のセンサ O信号，Ch，2 は右側（下流側）のセンサの信号である. まず図 3(a) に着目すると，得られる信号は長周期振 動と短周期振動の合成となっていることがわかる．さ らにCh.1 とCh.2にほぼ闹一の振動波形が現れ，上 流側 Ch.1 の波形は下流側 Ch.2 に対して約 0.5 秒進 んでいる.また図3(b) との比較から確認できるように， 本振動波形には走哩的な再現性がある。

次に被験者 4 名分の結果を図 4 に示す。それぞれ の被験者の信号について上記特徴力認められるが，異 なる被験者間で比較すると，得られる振動波形はそれ ぞれ明らかに異なっている。

\section{Front view Side view}

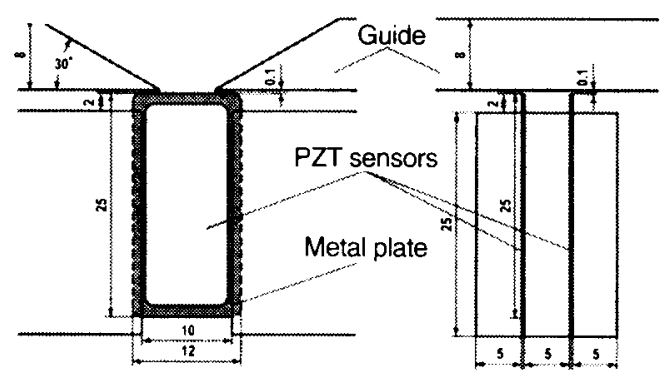

Fig.2 Schematic diagram around sensor unit 


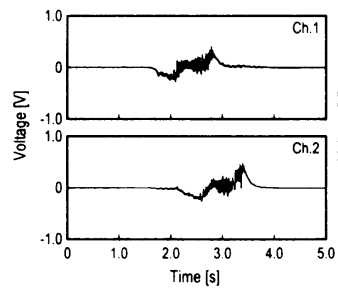

(a) 1 st trial

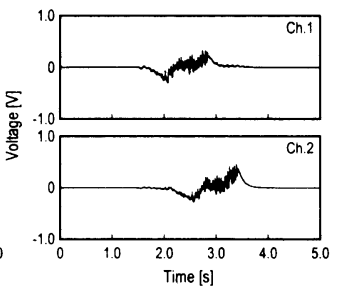

(b) 2nd trial
Fig. 3 Waveforms of subject A obtained by moving the sensor unit

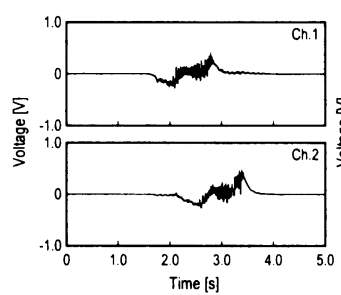

(a) Subject $\mathrm{A}$

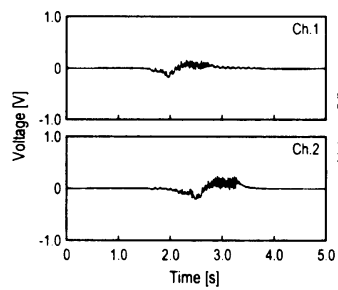

(c) Subject C

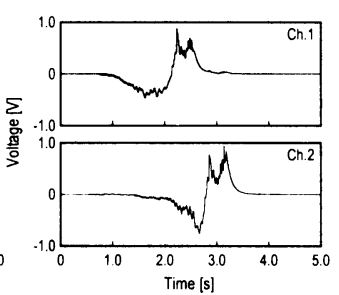

(b) Subject B

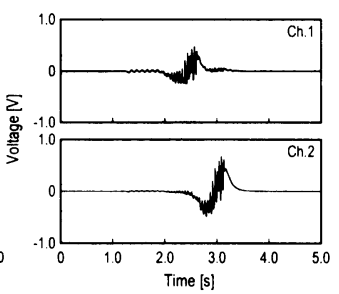

(d) Subject D
Fig. 4 Comparison with different subjects (waveforms obtained by moving the sensor unit)

以上の検討結果は，個々の身体的特徴に関する情報 が，同振動波形に含まれることを意味している．よっ て本摩摖信号は, 個人認証のための生体情報として, 必要条件を満たすことがわかる.

また, 上述の短周期振動の卓越周波数は20 $25 \mathrm{~Hz}$ 程度であり,これは指紋の隆線間隔 0.4 $0.5 \mathrm{~mm}$ ，センサユニットの移動速度 $10 \mathrm{~mm} / \mathrm{s}$ の関係 と定量的に一致する. さらにこの周波数がセンサの共 振周波数 $2300 \mathrm{~Hz}$ よりも十分低いことを考慮すると, 長周期振動は手指の立体的な形状と機械的性質 (粘弾 性）に起因し，指紋の立体的な凹凸により短周期振動 が付加されたと推察できる.

\section{$3 \cdot 2$ 行的特徽に関する検狽 本システムの} 摩擦信号は手指の身体的特徵を含むことが確認でき たので, 次にX軸直動ステージを静止した状態で, ガイドに沿って被験者の右手示指先端をすべらせて もらい，行動的特徴に関する検討を行った．ただし 手指の配置はX 軸負方向, すべりはX 軸正方向とし, その他のこすり方の詳細は個々に自由に決めてもら つた.

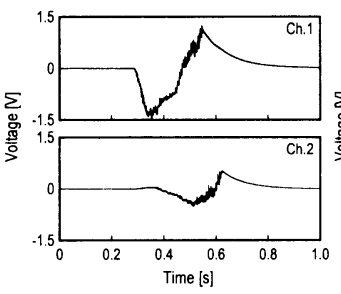

(a) 1st trial

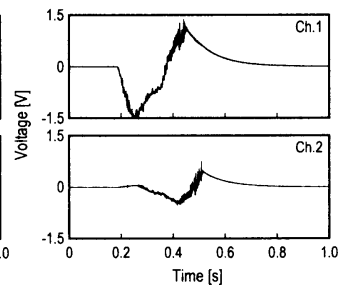

(b) 2nd trial
Fig. 5 Waveforms of subject A obtained by moving a finger

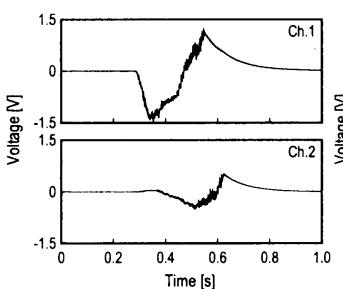

(a) Subject $\mathrm{A}$

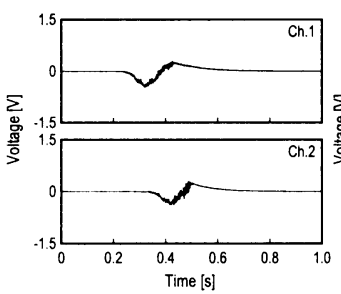

(c) Subject C

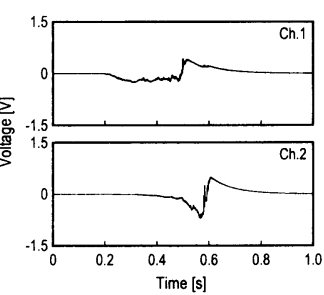

(b) Subject B

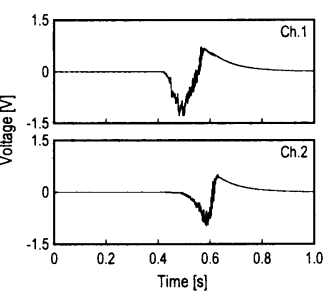

(d) Subject D
Fig.6 Comparison with different subjects (waveforms obtained by moving each finger)

被験者 $\mathrm{A}$ に同一のこすり方を 2 回要請した際の結 果を図 5 に示す。まず図 $5($ a) に着目すると，長周期 振動と短周期振動の合成波形となっていることは図 3 と共通しているが，得られる振動波形そのものか泪 3 の場合と異なっていること, さらにCh.1 の振動波形 とCh.2の振動波形に明確な差があることか特徴であ る. また図 5(b) との比較から，同一のこすり方をし た場合に得られる振動波形には，定量的な再現性か認 められる。

得られた振動波形を異なる被験者 4 名について比 較したものか図 6 である，それぞれの被験者の信号 について上記特徴か認められるが，異なる被験者間で 比較すると，得られる振動波形はそれぞれ明らかに異 なっている.

以上の検討結果は，個々の身体的特徴力決定する振 動波形を, 個々の行動的特徴 (押しつけ方・すべらせ方) が変化させることを意味しており，個人認証への応用 では，冒頭のコンセプトどおり，本摩摖信号が身体的 特徴と行動的特徴の両者を含む生体情報となること を示唆している. 


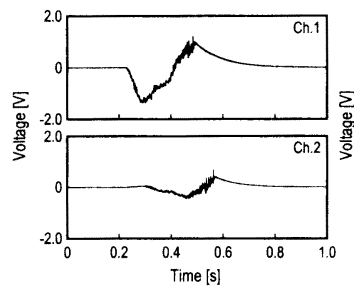

(a) Pattern 1

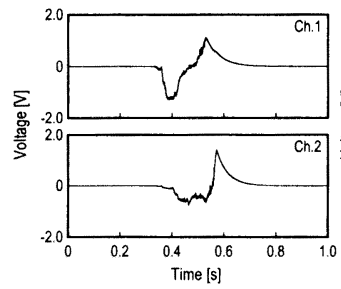

(c) Pattern 3

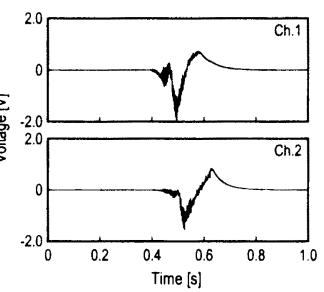

(b) Pattern 2

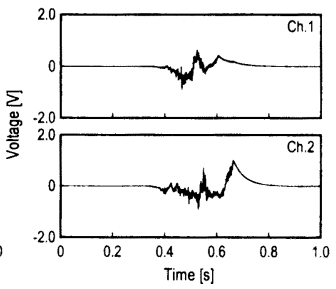

(d) Pattern 4
Fig.7 Change in waveforms by individual intention (subject A)

$3 \cdot 3$ 行動的特徵の任意性 前節で摩擦信号に 行動的特徴が含まれることを述べたが，こすり方は必 ずしも一意的でなく，行動的特徵には任意性があると 考えられる，そこで手指とセンサの接触位置，押付け 方，すべらせ方など，被験者にこすり方のパターンを 意識的に複数用意してもらい，3.2 節と同様な検討を 行った.

ここでは代表的に被験者 $\mathrm{A}$ の結果を図 7 に示す. 同図 (a) 〜 (d) すべて同一被験者の信号にも関わらず, 振動波形の異なる 4種類の信号か得られている. また, それぞれ4種類のパターンについて，図5に示した ような定量的再現性があることを確認した。

個人認証への応用を考える際，この行動的特徵の任 意性については 2 面性がある.この任意性を否定的 にとらえると，同一の手指を用いても異なる信号か溌 生することから，試行ごとのわずかなこすり方の違い によって, 本人を本人ではないと誤認し, 本人拒否率 が高くなる可能性がある．しかし肯定的にとらえるな らば，それぞれの信号パターンについて定量的再現性 か認められることから，本人がそのこすり方を正確に 記憶できさえすれば，より偽造に強い個人認証システ ムを構築できると考えられる.すなわち，本人のみが 知るそのこすり方自体が，従来の個人認証におけるパ スワードの役割を受け持つことになる．以上のような 2 面性のバランスをとるためには，センサユニットを はじめとするハードウェアと，照合アルゴリズムをは じめとするソフトウェアの両方向から，実用場面に即 した具体的検討が必要であろう.
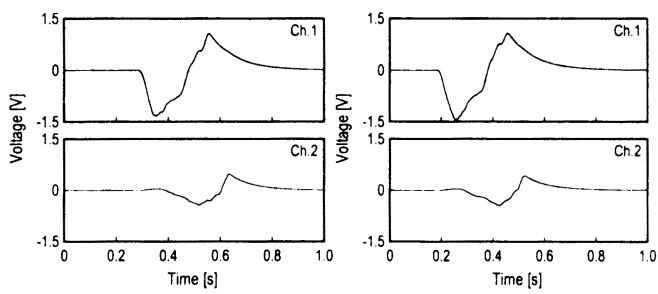

(a) Low-pass (1 st trial)

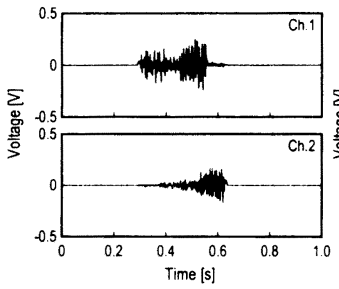

(b) Low-pass (2nd trial)

(c) High-pass (1st trial)

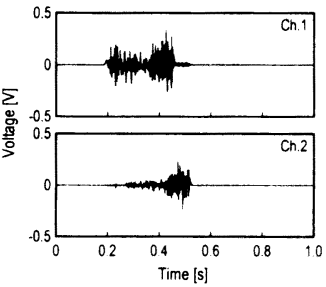

(d) High-pass (2nd trial)

\section{4. 蛙信号に基づく照合}

4・1 照合方法 被験者 14名 (男性：12名, 女性：2名，年秢：22〜26歳）を対象とし，3.2節 の方法で 2 回分の摩擦信号を取得して, 一方を標準 信号 (事前に個人登録された信号), 他方を入力信号 (照合時に入力する信号) とみなし，14×14（196 通 り）の照合を行った，ただし被験者には，行動的特徴
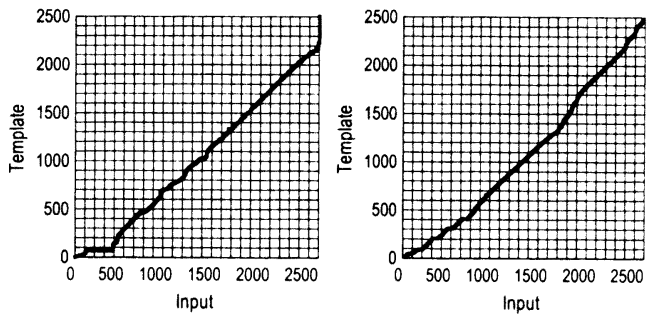

(a) Low-pass filtered signals (b) High-pass filtered signals

Fig.9 Optimized path between different two signals of subject $\mathrm{A}$
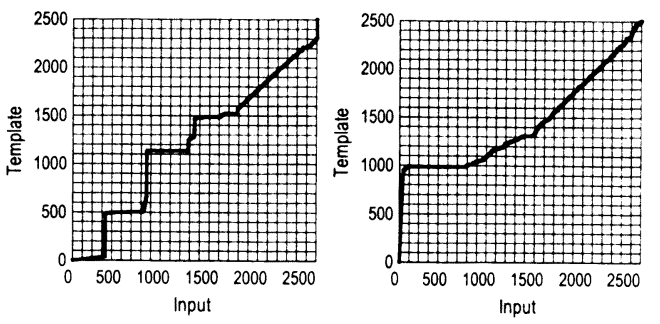

(a) Low-pass filtered signals (b) High-pass filtered signals

Fig.10 Optimized path between signals of subject $\mathrm{A}$ and subject B 
Table 1 Results of verification with dynamic programming (low-pass filtered signals)

\begin{tabular}{|c|c|c|c|c|c|c|c|c|c|c|c|c|c|c|}
\hline & Subject A & Subject B & Subject C & Subject D & Subjecte & Subject F & subject 0 & Subject H & Subject I & Subiectu & Subject K & Subiect & Subject M & subject N \\
\hline Subject A & 1.00 & 11.36 & 32.69 & 4.06 & 2.83 & 17.73 & 3.24 & 9.75 & 19.74 & 13.93 & 6.45 & 5.92 & 4.86 & 26.38 \\
\hline Subject B & 8.21 & 1.00 & 5.69 & 4.10 & 4.94 & 3.39 & 4.68 & 3.62 & 10.28 & 3.35 & 4.32 & 2.17 & 3.86 & 4.51 \\
\hline Subject C & 7.03 & 3.04 & 1.00 & 3.68 & 3.80 & 3.20 & 4.01 & 3.16 & 6.61 & 1.97 & 3.63 & 1.56 & 4.01 & 3.63 \\
\hline SubjectD & 2.31 & 6.53 & 19.41 & 1.00 & 1.01 & 8.55 & 1.48 & 5.71 & 7.62 & 7.92 & 2.34 & 3.44 & 1.98 & 13.96 \\
\hline Subject E & 2.87 & 6.30 & 17.25 & 1.07 & 1.00 & 7.61 & 1.53 & 5.32 & 5.81 & 7.11 & 1.65 & 3.24 & 1.92 & 12.25 \\
\hline Subjectf & 6.58 & 2.12 & 4.27 & 2.81 & 3.43 & 1.00 & 3.34 & 2.73 & 5.76 & 2.54 & 2.75 & 1.00 & 2.82 & 4.50 \\
\hline Subject G & 2.53 & 7.58 & 23.20 & 2.27 & 2.34 & 11.15 & 100 & 6.51 & 11.88 & 9.32 & 3.73 & 4.01 & 2.76 & 17.80 \\
\hline Sublect H & 6.75 & 2.57 & 7.37 & 3.53 & 4.32 & 5.31 & 3.54 & 1.00 & 9.94 & 4.93 & 4.36 & 1.67 & 3.38 & 6.40 \\
\hline Subject I & 4.54 & 3.63 & 7.82 & 1.74 & 1.93 & 3.61 & 1.96 & 3.41 & 1.00 & 3.09 & 1.57 & 1.76 & 2.42 & 6.33 \\
\hline Subject J & 7.31 & 3.20 & 4.39 & 3.70 & 3.94 & 3.72 & 4.04 & 4.22 & 6.95 & 1.00 & 3.55 & 2.21 & 4.04 & 3.69 \\
\hline Subject $K$ & 4.92 & 3.52 & 6.98 & 1.47 & 2.21 & 2.66 & 2.16 & 3.51 & 3.40 & 3.10 & 1.00 & 1.70 & 1.92 & 5.26 \\
\hline SubjectL & 5.78 & 3.56 & 10.75 & 2.56 & 3.52 & 3.81 & 2.60 & 3.03 & 6.55 & 4.68 & 3.09 & 1.13 & 2.47 & 9.13 \\
\hline Stbject M & 5.72 & 4.94 & 15.41 & 1.49 & 3.13 & 5.26 & 2.16 & 4.14 & 6.51 & 6.43 & 2.31 & 2.29 & 1.00 & 10.85 \\
\hline Subject N & 7.39 & 2.69 & 4.09 & 3.30 & 3.70 & 1.89 & 3.85 & 3.07 & 6.17 & 2.27 & 2.94 & 1.83 & 3.23 & 100 \\
\hline
\end{tabular}

Table 2 Results of verification with dynamic programming (high-pass filtered signals)

\begin{tabular}{|c|c|c|c|c|c|c|c|c|c|c|c|c|c|c|}
\hline & Subject A & Subject B & Subject C & Subject D & Subject $E$ & Subjoct $F$ & Subject 6 & Subject $\mathrm{H}$ & Subiectil & Subiect II & Subject K & SubjectL & Subjeat M & SibjectN \\
\hline Subject A & 1.00 & 3.28 & 2.94 & 1.71 & 2.22 & 1.78 & 1.79 & 1.74 & 3.82 & 1.65 & 2.70 & 1.67 & 1.62 & 3.19 \\
\hline Subject B & 1.43 & 1.00 & 1.42 & 1.50 & 1.30 & 1.24 & 1.46 & 1.25 & 1.58 & 1.20 & 1.56 & 1.42 & 1.17 & 1.80 \\
\hline Subject C & 1.25 & 1.41 & 1.00 & 1.41 & 1.16 & 1.13 & 1.35 & 1.20 & 1.59 & 1.07 & 1.74 & 1.16 & 1.08 & 1.68 \\
\hline Subject D & 1.40 & 2.59 & 2.66 & 1.00 & 1.86 & 1.36 & 1.66 & 1.41 & 3.06 & 1.62 & 2.03 & 1.42 & 1.30 & 2.18 \\
\hline Subject E & 1.22 & 1.53 & 1.51 & 1.27 & 1.16 & 1.02 & 1.28 & 1.10 & 1.73 & 1.16 & 1.56 & 1.13 & 1.00 & 1.49 \\
\hline Subject F & 1.40 & 2.53 & 2.41 & 1.19 & 1.81 & 1.05 & 1.56 & 1.13 & 2.84 & 1.45 & 1.73 & 1.33 & 1.19 & 1.98 \\
\hline Subject 6 & 1.34 & 2.33 & 2.27 & 1.53 & 1.68 & 1.42 & 1.00 & 1.37 & 2.67 & 1.37 & 2.03 & 1.44 & 1.29 & 2.23 \\
\hline Subject H & 1.42 & 2.66 & 2.36 & 1.35 & 1.84 & 1.27 & 1.52 & 1.00 & 2.93 & 1.52 & 1.81 & 1.33 & 1.16 & 2.09 \\
\hline Subject I & 1.21 & 1.05 & 1.18 & 1.32 & 1.00 & 1.08 & 1.28 & 1.15 & 1.00 & 1.08 & 1.46 & 1.26 & 1.06 & 1.36 \\
\hline Subject J & 1.22 & 1.89 & 1.82 & 1.51 & 1.46 & 1.32 & 1.43 & 1.39 & 2.23 & 100 & 2.08 & 1.30 & 1.26 & 2.04 \\
\hline Subject K & 1.40 & 1.57 & 1.85 & 1.14 & 1.37 & 1.10 & 1.35 & 1.08 & 1.84 & 1.36 & 1.00 & 1.35 & 1.09 & 1.48 \\
\hline SubjectL & 1.49 & 2.78 & 2.43 & 1.43 & 1.93 & 1.39 & 1.74 & 1.40 & 3.17 & 1.52 & 2.18 & 1.00 & 1.15 & 2.20 \\
\hline Subject M & 1.30 & 1.99 & 2.00 & 1.31 & 8.53 & 1.10 & 1.49 & 1.16 & 2.20 & 1.32 & 1.80 & 1.16 & 1.03 & 1.79 \\
\hline Subject $\mathrm{N}$ & 1.36 & 1.57 & 1.91 & 1.12 & 1.23 & 1.00 & 1.34 & 1.13 & 1.65 & 1.33 & 1.28 & 1.25 & 1.04 & 1.00 \\
\hline
\end{tabular}

Table 3 Total results of verification by low-pass and high-pass filtered signals (threshold: 2.20 )

\begin{tabular}{|c|c|c|c|c|c|c|c|c|c|c|c|c|c|c|}
\hline 84 & Subject A & Subject B & SubjoctC & Subject D & Subject $E$ & Subject $F$ & Subject G & Subject H. & Subject I & Subject J & Subject K & Subject L & Sublect M & Subfect N \\
\hline Sublect $A$ & 2.00 & 14.64 & 35.63 & 5.77 & 5.05 & 19.51 & 5.03 & 11.48 & 23.57 & 15.58 & 9.15 & 7.60 & 6.49 & 29.57 \\
\hline Subject B & 9.63 & 2.00 & 7.11 & 5.60 & 6.24 & 4.63 & 6.13 & 4.87 & 11.86 & 4.55 & 5.88 & 3.59 & 5.03 & 6.31 \\
\hline SubjectC & 8.27 & 4.45 & 2.00 & 5.09 & 4.96 & 4.33 & 5.37 & 4.36 & 8.20 & 3.04 & 5.37 & 2.72 & 5.09 & 5.31 \\
\hline Subject D & 3.71 & 9.13 & 22.07 & 2.00 & 2.87 & 9.91 & 3.13 & 7.12 & 10.68 & 9.54 & 4.36 & 4.85 & 3.29 & 16.13 \\
\hline Subject $E$ & 4.08 & 7.82 & 18.76 & 2.34 & 2.16 & 8.64 & 2.82 & 6.42 & 7.54 & 8.26 & 3.21 & 4.37 & 2.92 & 13.74 \\
\hline Subject $F$ & 7.98 & 4.65 & 6.68 & 4.00 & 5.24 & 2.05 & 4.90 & 3.86 & 8.60 & 3.98 & 4.48 & 2.33 & 4.02 & 6.48 \\
\hline Subject 6 & 3.87 & 9.91 & 25.47 & 3.80 & 4.03 & 12.57 & 2.00 & 7.88 & 14.54 & 10.69 & 5.75 & 5.45 & 4.05 & 20.03 \\
\hline Subject H & 8.17 & 5.23 & 9.73 & 4.88 & 6.16 & 6.59 & 5.07 & 2.00 & 12.86 & 6.45 & 6.18 & 3.00 & 4.54 & 8.49 \\
\hline Subject! & 5.74 & 4.68 & 9.00 & 3.06 & 2.93 & 4.69 & 3.24 & 4.56 & 2.00 & 4.18 & 3.03 & 3.02 & 3.48 & 7.69 \\
\hline Subject 3 & 8.53 & 5.09 & 6.21 & 5.22 & 5.40 & 5.04 & 5.47 & 5.61 & 9.18 & 2.00 & 5.63 & 3.52 & 5.31 & 5.74 \\
\hline Subject K & 6.32 & 5.10 & 8.83 & 2.61 & 3.58 & 3.76 & 3.51 & 4.59 & 5.24 & 4.46 & 2.00 & 3.05 & 3.01 & 6.74 \\
\hline Subject L & 7.28 & 6.34 & 13.18 & 3.99 & 5.45 & 5.20 & 4.33 & 4.43 & 9.72 & 6.20 & 5.27 & 2.13 & 3.62 & 11.33 \\
\hline Subject M & 7.03 & 6.94 & 17.41 & 2.81 & 4.66 & 6.36 & 3.64 & 5.30 & 8.71 & 7.75 & 4.11 & 3.46 & 2.03 & 12.65 \\
\hline Subject $N$ & 8.75 & 4.25 & 6.00 & 4.41 & 4.93 & 2.89 & 5.20 & 4.20 & 7.82 & 3.60 & 4.22 & 3.09 & 4.27 & 2.00 \\
\hline
\end{tabular}

を利用することを通知した上で，自由な動作での試行 を依頼した。 なお，1名の被験者の実験に要した時間 は，動作に慣れるための練習時間を含めて約 5 分で あった。

照合計算の前に，すべての標準信号と入力信号に ディジタルフィルタ処理を施し，低域通過信号と高域 通過信号に分割した，今回の害験では，いずれの被験 者の場合も, 先述した短周期振動の卓越周波数が 150 〜 200Hz 程度となったので，低域通過信号に先述の 長周期振動，高域通過信号に短周期振動が含まれるよ うに，周波数の閾值は $30 \mathrm{~Hz}$ とした．図 5 に示したデ 一タについて，同処理を施した結果を図 8 に示す。

本照合では, 動的計画法に基づき 2 系列の離散信
号を対応づけ，一方の信号の横軸（時間軸）に最適な 非線形伸縮を施す DP マッチング(4) (6) を用いて，標 準信号と入力信号の距離計算を行った.

チャンネル数 $\mathrm{N}$ の離散信号を $\mathrm{N}$ 次元ベクトル $\mathrm{a}$, $b_{j}$ で表記し，対応づけるべき信号列 $A\left(a_{1}, a_{2}, \cdots, a_{1}\right.$, $\left.\cdots, a_{1}\right)$, B ( $\left(b_{1}, b_{2}, \cdots, b_{j}, \cdots, b_{j}\right)$ からなる平面を考えると, $\mathrm{A}, \mathrm{B}$ 両信号列間の時間軸の対応関係は，この平面上

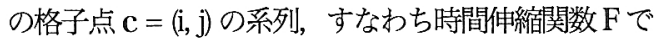
表すことができる.

$$
\mathbb{F}=\left(\mathbf{c}_{1}, \mathbf{c}_{2}, \cdots, \mathbf{c}_{\mathrm{k}}, \cdots, \mathbf{c}_{\mathrm{K}}\right), \quad \mathbf{c}_{\mathrm{k}}=\left(\mathrm{i}_{\mathrm{k}}, \mathrm{j}_{\mathrm{k}}\right)
$$

$\mathbf{a}_{1}$ と $\mathbf{b}_{\mathrm{j}}$ との距離を $\mathrm{d}(\mathrm{c})=\mathrm{d}(\mathrm{i}, \mathrm{j})$ とすると, 系列 $\mathrm{F}$ に沿 った距離の総和は次式で表される。 


$$
\mathrm{D}(\mathbb{F})=\sum_{\mathrm{k}=1}^{\mathrm{K}} \mathrm{d}\left(\mathbf{c}_{\mathrm{k}}\right) \cdot \mathrm{w}_{\mathrm{k}} / \sum_{\mathrm{k}=1}^{\mathrm{K}} \mathrm{w}_{\mathrm{k}}
$$
ただし，

$$
\begin{aligned}
& \mathrm{d}(\mathbf{c})=\left|\mathrm{a}_{\mathrm{i}}-\mathrm{b}_{\mathrm{j}}\right| \\
& \mathrm{w}_{\mathrm{k}}=\left(\mathrm{i}_{\mathrm{k}}-\mathrm{i}_{\mathrm{k}-1}\right)+\left(\mathrm{j}_{\mathrm{k}}-\mathrm{j}_{\mathrm{k}-1}\right)
\end{aligned}
$$

ここで, $\mathrm{w}_{\mathrm{k}}$ はFに関連した正の重み係数であり，1 または2の值をとる。

距離D(的)の值を最小にするような最適マッチング 系列 $\mathrm{F}_{\mathrm{opt}}$ は，動的計画法(9) 一(1) を用いることにより見 つけることができる。そして最適経路において得られ た距離が小さいほど，兩信号は似ているとみなすこと ができる。ただし今回は，低域通過信号捛よび高域通 過信号の距離を個別に計算・規格化し，両者の和を評 価值とした。最終的には評価値に適切な閾值を設ける ことにより，被験者 14名の識別を試みた。

4.2 照合結照 例として，被験者 $\mathrm{A}$ の標準信 号と同者の入力信号の最適マッチング系列を园 9 , 同 標準信号と被験者 Bの入力信号の最適マッチング系 列を図 10 に示す。本プロットでは，時間軸の非線 形种縮なしに 2 系列の離散信号が対応付けられると， 右斜め上 45 度に点が結ばれる。

同一被験者信号の対応付けを表す図 9では，同図 (a) の低域通過信号，(b) の高域通過信号ともに45度 の線分が多く現れて招り，図8で述べた信号の類似 性を改めて確讃することができる。一方，異なる被 験者間の信号を刘応付けた図 10 では，低域通過信号 そ高域通過信号ともに不連続なステップが現れ，南 者の非類似性を示唆している.

低域通過信号および高域通過信号それぞれについ て，DPマッチン゙グにより得られた規格化距離を表 1 , 2 に示す。ここで䙺格化距離とは，亦る被験者の入力 信号について，すべての被験者の標準信号に対する 距離 $\mathrm{D}\left(\mathbb{F}_{\text {opt }}\right)$ を求め，その最小值で除すことにより規 格化した量である，同表では，ある被験者の入力信号 に対する規格化距離の值を表中の列に示し，その最 小值のセルの色を,反転して表示してある，その結果， ほとんどすべての組合せについて，同一被験者の場 合の距離が最小となったが，異なる被験者同士の距 離が最小となる場合が低域通過信号に 1 組，高域通 過信号に 3 組現れた。

総合的な判定の試みとして，低域通過信号（表 I） と高域通過信号（表 2）の值を単純に加算して得られ る評価値を表 3 に示す。同表の評価値に対して閾值 を2.20 とし，その値を下回るセルの色を反転して表 示した。結果として本実験に扢いては，本条件を满た
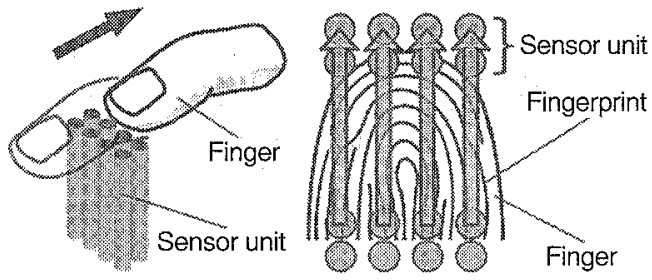

Fig.11 Array type sensor unit

すのは，標潐信号と入力信号か洞一被験者の場合に限 られていることから，本手法によって被蛤者14名全 員を完全に識別できたことがわかる。

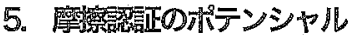

以上の実験的検討により，摩擦信号を生体情報とし て用いた摩擦認証は，身体的特徵と行動的特徵を利用 したバイオメトリクス認証法として，十分条件を満た していることを示した，また，すべり摩擦方向に力感 知型センサを 2 枚配犆することで，行動的特徴を抽 出できることか明らかになった。

既存のバイオメトリクス認証法の1つに声紋認証 がある、我々か溌する声は, 個々の発音器官の振動音 響学的特性に基づく身体的特徽を利用し，その上でし やべり方という行動的特徵を利用している，すなわち 而特街を利用しているという点で，摩祭認証と声紋認 証には共通点がある。

しかし声紋認証か利用できる生体情報は，1 系列の 音声信号のみである。また音声の録音・再生による偽 造に対して脆弱である点が問题視されている，一方， 摩際認証正の場合には，俿造困難な触覚情報を利用して 抢り，力感知型センサの数を増やせば，その分だけ利 用できる情報量力嗍曽加する。

例总ば図11 に示すように，接触面内にアレイ化し た縦 $2 \times$ 横 4 チャンネルの力感知型センサユニットを 考党る，センサを縱 (すべり摩擦方向) に配置すると， 行動的特徵を抽出できることは先に述べたと㧍りで ある，一方，横に配䈯した場合には，図中4列のセ ンサ性指紋の異なる場所を走査するので，そ扎ぞれ独 立した身体的特徴を得ることができる，すなわち縱横 のチャンネル数の適切な配分により，身体的特徴と行 動的特徽のバランス，言い換光れば，認証率之碩強性 のバランスをとることができる。このようなセンサの アレイ化と，それにともなう照合アルゴリズムの開発 が、本研究の次の課題である。

\section{6. おわりに}

手指の摩擦信号を生体情報として利用する，バイオ 
メトリクス譛証の新たな手法を提案した。試作システ ムを用いた実験的検討により，次のことか淜らかにな った.

（1）手指の摩擦信号には，身体的特徵と行動的特徵の 両者が含まれる。

(2) 摩擦信号に及ぼす行動的特徵の影響は一意的で なく, こすり方によって, 同一の手指でも複数 の異なる信号が発生する，ただしそれぞれの信 号には，十分な再現性がある。

（3）上記性質を有する手指の摩摖信号は，個人認証の ための生体情報として利用可能である.

(4) 手指の摩擦信号を利用したバイオメトリクス認 証のための照合アルゴリズムとして，DPマッチ
ングは有効である.

\section{文献}

(1) 日本自動認識システム協会, これでわかったバイオメ トリクス, (2001), オーム社.

(2) 瀬戸洋一，サイバーセキュリティにおける生体認証技 術, (2002), 共立出版.

(3) J.D.Woodwand, N.M.Orlans and P.T.Higgins, Biometrics, (2003), MoGraw-Hill.

(4) 上坂吉則・尾関和彦, パ夕ーン認識と学習のアルゴリ ズム, (1990), 文一総合出版.

（5）吉井貞熙，音声情報処理，(1998), 森北出版.

（6）春日正男·船田哲男・林伸二・武田一哉，音声情報処理， (2001), コロナ社. 